\title{
PIELGRZYMKA PAWLA VI DO ZIEMI ŚWIĘTEJ
}

Dnia 4 grudnia 1963 r., Ojciec Święty Paweł VI w swoim przemówieniu zamykającym drugą sesję II Soboru Watykańskiego, podał Ojcom Soboru do wiadomości swoją decyzję udania się z pielgrzymką do Ziemi Świętej. Wiadomość ta rozniesiona na falach eteru po całym globie ziemskim, zelektryzowała niemal dosłownie całą ludzkość. Była to sensancja nie mająca miejsca od Janowej zapowiedzi zwołania Soboru, ogłoszonej w bazylice św. Pawła za murami 25 stycznia 1959 r.

Na wiadomość o decyzji Papieża Pawła VI udania się z pielgrzymką do Ziemi św., ambasador Izraela Fischer oświadczył, że jego rząd uczyni wszystko, by ułatwić Ojcu św. zwiedzanie miejsc świętych. W Jordanii natomiast zabrał głos sam król Hussein, podkreślając, że Paweł VI będzie oficjalnym gościem jego rządu. Toteż rządy oraz ludność obydwu krajów poczyniły ogromne przygotowania na przyjęcie Dostojnego Pielgrzyma. Muzułmański burmistrz Nazaretu ogłaszając decyzję nazwania jednej z ulic tego miasta imieniem Pawła VI, - wyraził swą radość, że wizyta $\mathrm{P}:$ pieża przypada na jego kadencję. Rada Miejska Betlejem przesłała do Stolicy Apostolskiej depeszę wzruszającej treści: Wyciagamy do Was (Ojcze św. - przyp. mój) ręce, otwieramy nasze serca na Wasze powitanie. Wreszcie w Tel Avivie wydana została specjalna proklamacja Wielkiego Rabina Izraela: Za kilka dni przybędzie Wielki Pielgrzym - Papież Paweł VI, aby wznieść swe modły na Ziemi świętej. Niech otrzyma On obfite błogosławieństwo Syonu Swiẹtej Góry Pana, oraz Jerozolimy - Miasta Wybranego. Niech też jego modlitwy zostana wystuchane $w$ tej ciszy i w tym spokoju, jakiego On pragnie $i$ jakie odpowiadaja duchowi modlitewnemu

Ożywiły się również jeszcze bardziej kontakty z Konstantynopoliłańskim Patriarchatem Ekumenicznym. Zaledwie w cztery dni po przemówieniu Namiestnika Chrystusowego, zapowiadającym jego pielgrzymkę do Ziemi św., Patriarchat ten opublikował komunikat, który informował, że Patriarcha Ekumeniczny Konstantynopola A tenagoras I proponuje $w$ Jerozolimie podczas pobytu $\mathrm{Pa}-$ pieża w Palestynie spotkanie wszystkich Zwierzchników Kościoła Wschodu i Zachodu. We wspólnej, goracej modlitwie, w nabożnym zespoleniu, na kolanach $i$ ze łzami $w$ oczach, $w$ duchu jedności, na tym świętym miejscu, zroszonym Krwia Zbawiciela, miejscu, z którego popłynęta pociecha $i$ przebaczenie, modliliby sie oni o to, by dla chwaty Chrystusa i dla dobra całej ludzkości, otworzyły się drogi pełnej jedności chrześcijańskiej, której życzył sobie Bóg. Sugestię Atenagoras a I przyjęto w Watykanie niezwykle ciepło i przychylnie. W konsekwencji, po szeregu zabiegach dyplo- 
matycznych, doszło na palestyńskiej ziemi do spotkania, wprawdzie nie wszystkich Zwierzchników Kościołów Wschodu i Zachodu, jak sugerował Ekumeniczny Patriarcha, ale jego i Papieża.

Pielgrzymka Ojca św. Pawła VI do Ziemi świętej miała miejsce w dniach 4-6 stycznia br., a poprzedzona została specjalnymi rekolekcjami Papieża i towarzyszących jego podróży osobistości, odbytymi 2 stycznia w kaplicy św. Matyldy Pałacu Apostolskiego w Watykanie pod przewodnictwem O. J. Devilaque.

W sobotę - 4 stycznia, punktualnie o godz. $7^{10}$ dwusetny sześćdziesiąty i trzeci Następca św. Piotra opuścił Watykan, udając się samochodem na oddalone o $30 \mathrm{~km}$ od Miasta Watykańskiego lotnisko Fiumicino. Mimo wczesnego, ale pogodnego poranka na trasie przejazdu żegnały Papieża okrzykami i oklaskami radości nieprzeliczone rzesze mieszkańców Wiecznego Miasta (była m. in. i grupa więźniów Regina Coeli ze swymi kapelanami). Na granicy państwa Watykańskiego i Włoch Paweł VI został powitany przez delegacje rzaclu włoskiego $\mathrm{z}$ ministrem spraw zagranicznych $\mathrm{S}$ a $\mathrm{r}$ a g t $\mathrm{e} \mathrm{m}$ na czele. Oficjalne pożegnanie przed odlotem do Ziemi św. miało miejsce na lotnisku Fiumicino. Oczekiwał tam Dostojnego Pielgrzyma: Prezydent Włoch Segni wraz z rząem włoskim i korpusem dyplomatycznym akredytowanym przy Stolicy Apostolskiej i Kwirynale in corpore, setki dziennikarzy, fotoreporterów, sprawozdawców radiowych i telewizyjnych (odlot Papieża transmitowała Eurowizja). Przemówienia wygłosili: prezydent Seg n i i Ojciec św., l.tóry powiedzial $\mathrm{m}$. in.: ...pragniemy, by ta pielgrzymka była powrotem do kolebki chrześcijaństwa, gdzie ewangeliczne ziarno gorcz!czne zapuścito pierwsze korzenie, rozrastajac sie nastepnie w wielkie drzewo ocieniajace cały świat. Pragniemy, żeby ta pielgrzymka była wizyta modlitwy na miejscach uświęconych życiem, Męka i Zmartwychwstaniem naszego Pana. ...Będziemy prosili Księcia Poicoju, o ten cenny dar dla świata i o coraz lepsze umocnienie go wśród ludzi, rodzin i narodów. Przedstawimy Chrystusowi Jego Kościół Powszechny i jego pragnienia, aby zawsze był wierny przykazaniom miłości i jedności, które Chrystus pozostawił jako Swoja ostatnia wolę.

Do pomalowanego na biało, $z$ herbem Pawła VI i papiestwa w polu, czteromotorego odrzutowca Alitalia, którego załogę stanowili wytrawni piloci włoskiego lotnictwa (samolot odbywał przedtem dwa próbne loty do Ammanu), a na pokładzie którego zajęły już miejsca osoby towarzyszące Papieżowi $\mathrm{m}$. in.: kardynałowie: E. Tisserant, A. Cicognani i G. Teesta, dwaj sekretarze Ojca św., Ks. L. Capovilla - sekretarz osobisty Jana XXIII i trzej kamerdynerzy, podprowadził Dostojnego Pielgrzyma - pre- 
zydent Włoch Segni. Uściski dłoni, błogosławieństwa papieskie ze schodków samolotu, serdeczny gest pożegnania z otwartych drzwi i samolot wystartowal a za nim honorowa ekskorta i samoloty wiozące dziennikarzy.

Z pokładu odrzutowca Papież przesłał na ręce przywódców państw, nad terytorium których przelatywał depesze, a mianowicie: do króla P a wła i narodu greckiego, do prezydenta Cypru arcybiskupa Makarios a oraz do prezydentów Libanu i Syrii.

Tymczasem istniały obawy, że szalejąca nad Palestyną już od godzin nocnych wichura, która zniszczyła wspaniałe dekoracje, uniemożliwi lądowanie papieskiego samolotu w Ammanie - stolicy Jordanii. Byly nawet propozycje skierowania go na lotnisko w Bejrucie. W ostatniej niemal chwili pogoda poprawiła się i o godz. $12^{14}$ lądowanie odbyło się spokojnie w stolicy Jordanii. Gdy biała sylwetka Chrystusowego Namiestnika ukazała się w drzwiach odrzutowca, zebrane mimo przejmującego zimna i deszczu tysięczne rzesze ludzkie, wiwałowały na cześć Dostojnego Gościa, przy akompaniamencie dwudziestu jeden powitalnych salw armatnich, tysiącach wypuszczonych w powietrze białych gołębi, prezentującej broń Królewskiej Gwardii oraz błysku fleszy i kamer 1150 dziennikarzy, fotoreporterów i pracowników telewizji. Na płycie lotniska a potem w salonie lotniczego dworca $\mathrm{P}$ a w $ł$ a VI powitał sam król Jordanii Hussein, krótkim, ale głębokim i nadzwyczaj życzliwym przemówieniem w języku angielskim. W tym samym języku odpowiedział również Papież. Po wymianie podarunków, w towarzystwie honorowej ekskorty motocyklistów Gwardii Królewskiej biała limuzyna z Zastępcą Jezusa na ziemi, przedzierając sie poprzez tłumy ruszyła do Jerozolimy. U granic Świętego Miasta Dostojnego Pielgrzyma powitał tamtejszy Burmistrz. Na moście, przed wielkim łukiem triumfalnym, przybranym flagami papieskimi i jordańskimi oraz kwiatami Ojciec św. wysiadł z samochodu i po specjalnych schodach zszedł na brzeg rzeki Jordanu, by po dwóch tysiącach lat powtórzyć gest św. Jana Chrzciciela, zanurzając swe rẹce w wodę rzeki. W tym momencie nad Jordanem pojawił się helikopter króla Husseina w asyście samolotów wojskowych.

Od bramy Damasceńskiej, przy wtórze bijących dzwonów wszystkich kościołów Jerozolimy, wzruszony, rozmodlony, wciąż błogosławiący i rozdający przyjazne gesty Papież szedł pieszo szlakiem Krzyżowej Drogi Chrystusowej, całując na klęczkach miejsca Jego zbawczych upadków. Tu już pękły wszelkie kordony porządkowe policji. Na wąskich uliczkach świętego Miasta tłumy były tak ogromne iż była obawa poturbowania Ojca św. I istotnie, Papież raz nawet musiał chronić się przed nimi do napotkanej klasztornej bramy. 
W Bazylice Jezusowego Grobu, do której z racji wielkiego ścisku nie dostały się nawet wszystkie osobistości towarzyszące papieskiej pielgrzymce, po żarliwej modlitwie u kamienia grobowego, P awe $ł$ VI ze wzruszeniem celebrował wotywę o Zmartwychwstaniu Pańskim. Przy czytaniu Ewangelii, w miejscu, gdzie anioł odsyła niewiasty do Galilei, bo „tam Go zobaczą", głos mu się załamał i z trudem doczytał do końca, podobnie załamał mu się głos podczas Prefacji, a w czasie Podniesienia Papièż płakał.

Po Mszy św. Ojciec św. odprawił głośno krótką medytację o Krzyżu św., udając się następnie do pałacyku Delegatury Apostolskiej na zboczu Getsemani. Tam, po krótkim odpoczynku i obiedzie, przyjął gości jerozolimskich, a m. in. także Patriarchę prawosławnego Jerozolimy B en ediktos a, o którym wiadomo, że był przeciwnym spotkaniu Papieża $\mathrm{z}$ A t e $\mathrm{n}$ a g or a s e m I, a nawet miał wysłać - na próżno zresztą - swych delegatów do Konstantynopola, by Patriarsze przyjazd do Jerozolimy odradzali.

Ostatnim, oficjalnym wystąpieniem Dostojnego Pątnika w tym dniu, był jego udział w godzinie świętej w Bazylice Narodów w Getsemani na Górze Oliwnej, podczas której odczytano także urywki z Ewangelii o Męce Chrystusowej w Ogrójcu w sześciu językach: łacińskim, greckim, arabskim, koptyjskim, rosyjskim, oraz ormiańskim.

Dzień 5 stycznia był izraelskim dniem papieskiej pielgrzymki. Tego dnia Paweł VI pielgrzymował do miejsc świętych leżących na terenie Izraela. Z prawie dwugodzinnym opóźnieniem w stosunku do przewidzianego programu, spowodowanym przez arabskie, wiwatujące tłumy, granicę Izraela przekroczył Ojciec św. przez nowo odbudowaną bramę Taana, w pobliżu historycznego Megiddo, będącego świadkiem chwały i upadku Wybranego Narodu. Przejście to otwarto specjalnie dla Papieża. Normalnie ruch pomiędzy Jordanią i Izraelem odbywa się tylko przez Bramę Drzewa Migdałowego w Jerozolimie. W Bramie Taana oczekiwał już Prezydent Izraela: Shazar, premier Eshkol, członkowie rządu i korpus dyplomatyczny. A oto charakterystyczne zdania $\mathrm{z}$ powitalnego przemówienia prezydenta: $Z$ glębokim szacunkiem $i z$ pełna świadomościa olbrzymiego znaczenia historycznego, tego wydarzenia bez precedensu na przestrzeni pokoleń, w imieniu państwa Izrael i moim własnym przybyłem tutaj, aby powitać Papieża, Ojca duchowego wiernych rzymskiego Kościoła katnlickiego, pozdrawiajac Go tradycyjnym błogosławieństwem: badź pozdrowiony na naszej ziemi. Niemniej znamienne są słowa P a w 1 a VI: Jako pielgrzym pokoju prosze przede wszystkim o pogodzenie sie czlowieka $z$ Bogiem oraz o głęboka i szczera zgode pomiędzy wszystkimi ludźmi i między narodami o: szalom, szalom. 
Naz ret - miasto Zwiastowania Narodzin Boga - Człowieka i zamieszkiwania św. Rodziny po Jej powrocie z Egiptu, było pierwszym etapem papieskiej pielgrzymki w Izraelu. Po uroczystych powitaniach, oczywiście przy udziale tłumów okolicznej ludności, przybyłej wszelkimi, dostępnymi jej środkami lokomocji, nawet na osiołkach, Papież celebrował w grocie bazyliki Zwiastowania Mszę św. transmitowaną przez radio i telewizję i przemówił m. in. o znaczeniu rodziny.

W drodze nad Jezioro Galilejskie, czyli Tyberiadzkie, w Ewangeliach nazywane Genezaret, Dostojny Pątnik zatrzymał się w K anie Galilejskiej - miejscu cudownego przemienienia wody w wino i uzdrowienie syna setnika królewskiego z Kafarnaum, w Tobgha - miejscu zapowiedzi papieskiego prymatu oraz w Kafarnaum, gdzie obejrzał ruiny starej synagogi. Stojąc nad brzegami jeziora Genezaret Papież zanurzył swoje ręce w wodzie, o którą odbijało się echo ewangelicznych słów Chrystusa. Klasztor włoskich franciszkanek na Górze Błogosławieństw gościnnie podejmował Ojca św. obiadem, skąd po krótkim wypoczynku stanął u stóp Tahoru. Tam tė̇ doznał szczególnie gorącego przyjęcia. W drodze do Bazyliki Przemienienia Pańskiego biły wszystkie dzwony, a trasa, którą przechodził dosłownie usłana została kwiatami.

Ostatni etap papieskich nawiedzin miejsc uświęconych stopami Boskiego Zbawiciela po izraelskiej stronie to Jerozolima, z Górą Syonem - miejscem tradycyjnego Zaśnięcia NMP i Wieczernikiem. Gdy Ojciec św. zwiedzal Wieczernik kard. Tisserant w towarzystwie rządu izraelskiego zapalił w imieniu Papieża sześć świec w pobliskiej Grocie Męczenników na uczczenie sześciu milionów Żydów pomordowanych w czasie drugiej wojny światowej.

Powracającego do pałacu Delegatury Apostolskiej po stronie jordańskiej Pielgrzyma żegnał przy bramie Mendelbauma, czyli Migdałowego Drzewa sam prezydent Izraela w specialnie na ten cel zbudowanym pawilonie. Przemówienia tu wygłoszone były nadzwyczaj cieple i przyjazne.

Wieczorem 5 stycznia miał miejsce kulminacyjny punkt pielgrzymki Piotrowego Następcy: spotkanie w Delegaturze z prawosławnym Patriarchą Konstantynopola A ten a gor a s em I, który przybył tego dnia, witany w Ammanie podobnie uroczyście jak $\mathrm{P}_{2}$ pież. Wizyta Atenagor as a I trwała około 40 minut i zakończyła się wspólnym odmówieniem Ojcze Nasz w języku greckim oraz historycznym już obecnie pocałunkiem pokoju.

Trzeci i ostatni dzień pobytu - 6 stycznia - Ojca św. na palestyńskiej ziemi zbiegł się z uroczystością Epifanii. Rankiem Papież udał się do oddalonego o $10 \mathrm{~km}$ od Jerozolimy - Betlejem, poprzedzany honorową eskortą dwudziestu jeźdźców Gwardii Kró- 
lewskiej na białych, arabskich koniach, w towarzystwie lecącego szkarłatnym helikopterem króla $\mathrm{H}$ u s e in a. W Bazylice Pańskiego Narodzenia odprawił Mszę św. oraz wygłosił dłuższe przemówienie, w którym jak złota nić przewijała się myśl ekumeniczna. Było to nawiązanie do mającego miejsce poprzedniego dnia wieczorem spotkania z Patriarchą Konstantynopola i mającą dopiero nastąpić jego rewizyta. Właśnie tuż po powrocie z Betlejem. Ojciec św. P awe $ł$ VI rewizytował Ekumenicznegu Patriarchę Konstantynopola Atenagorasa I w rezydencji prawosławnego Patriarchatu Jerozolimy, znajdującej się zaledwie w pięciuset metrowej odległości od siedziby Delegatury Apostolskiej. Rozmowy, które rozpoczęły się Jezusową modlitwą o jedność wypowiedzianą podczas Ostatniej Wieczerzy a zawarta w Ewangelii św. Jana, trwały około dwu godzin, przy udziale trzech kardynałów i Msgr'a Willenbrandsa z Sekretariatu Jedności Chrześcijan. Na zakończenie Paw e PI podarował Atenagorasowi I złoty kielich mszalny i patenę. Otrzymał zaś od Patriarchy starą ikonę, bogato inkrustowaną brylantami i rubinami oraz złoty krzyż z łańcuchem. Jeszcze jedno spotkanie Papieża i Patriarchy, tym razem przypadkowe, miało miejsce na ulicach Jerozolimy, w drodze P a w 1 a VI na lotnisko w Ammanie.

$\mathrm{Na}$ dworcu lotniczym. w Ammanie oczekiwał już Papieża król Hussein z całym rządem i korpusem dyplomatycznym. W odøowiedzi na pożegnalne przemówienie króla Ojciec św. wyrażając podziękowanie za tak gorące przyjęcie zgotowanie mu na Ziemi świętej przez jej mieszkańców powiedział m. in.: Niech Bóg wynagrodzi te serdeczność, niech otrze wszystkim łzy, niech ześle im pokój, dobrobyt $i$ prawdziwe szczęście. Pokój tej ziemi i wszystkim jej mieszkańcom. W chwilę potem, przy akompaniamencie dwudziestu jeden salw armatnich odrzutowiec DC 8 oderwał się od palestyńskiej ziemi i ,wziął kurs" na Wieczne Miasto.

Przygotowujący się od trzech dni na powitanie Dostojnego Pielgrzyma Rzym dosłownie cały wyległ na trasę powrotu. Entuzlazm był przeogromny; od lotniska, na którym przywitał Papieża prezydent Segni wraz z rządem, aż po Plac Bazyliki św. Piotra. Dzwony, wiwaty i pochodnie; motocykle, kwiaty i flagi. Tak zreszta powinna zakończyć się ta niewątpliwie historyczna, o wysokim walorze ideologicznym i moralnym pierwsza Pielgrzymka śladami Boskiego Zbawiciela i Księcia Apostołów św. Piotra i Ich Zastẹpcy i. Następcy. 